\title{
The Working Memory as Predictor of Performance in Arithmetic of Brazilian Students
}

\author{
Fernanda David Vieira ${ }^{1}$ \\ Denise Oliveira Ribeiro ${ }^{2}$ \\ Heitor Blesa Farias ${ }^{2}$ \\ Patricia Martins Freitas ${ }^{1}$
}

\begin{abstract}
Working memory (WM) is a predictor of school learning. This study aimed to investigate the predictive power of verbal and non-verbal working memory (WM) on students' performance in arithmetic. 126 children between 6 and 11 years old participated in the research. The instruments were: School Performance Test, Raven's Colored Progressive Matrices, Corsi Block-tapping Test, and Digits Subtest. The results showed strong and positive correlations of school performance with fluid intelligence $r=0.64$, with verbal WM and non-verbal WM, both with $r=0.51(p<0.001)$. After multiple linear regression, it was found that the performance in visuospatial WM was a strong predictor for arithmetic, an effect not found for reading. The regression showed that WM explains $38 \%$ of the variance for arithmetic. It is concluded that WM has an expressive contribution to school performance, being more specific the contributions of visuospatial WM for arithmetic.
\end{abstract}

Keywords: working memory, mathematics, children, academic achievement

\section{A Memória de Trabalho como Preditora do Desempenho em Aritmética de Escolares Brasileiros}

\begin{abstract}
Resumo: A memória de trabalho (MT) é um preditor da aprendizagem escolar. Este estudo teve por objetivo investigar o poder preditivo da memória de trabalho (MT) verbal e não verbal sobre o desempenho da aritmética. Participaram 126 crianças entre 6 e 11 anos. Os instrumentos foram: Teste de Desempenho Escolar, Matrizes Progressivas Colorida de Raven, Cubos de Corsi e Subteste Dígitos. Os resultados demonstraram correlações fortes e positivas do desempenho escolar com inteligência fluida $r=0,64$ com MT verbal e com a MT não verbal, ambas com $r=0,51(p<0,001)$. Após regressão linear múltipla, verificou-se que o desempenho na MT visuoespacial foi um forte preditor para a aritmética, efeito não encontrado para a leitura. A regressão demonstrou que a MT explica 38\% da variância para a aritmética. Conclui-se que a MT tem uma contribuição expressiva para o desempenho escolar, sendo mais específicas as contribuições do esboço visuoespacial para a aritmética.
\end{abstract}

Palavras-chave: memória operacional, matemática, crianças, rendimento escolar

\section{La Memoria de Trabajo como Predictor de Rendimiento en Aritmética de Escolares Brasileños}

\begin{abstract}
Resumen: La memoria de trabajo (MT) es un predictor del aprendizaje escolar. Este estudio tuvo como objetivo investigar el potencial predictivo de la MT verbal y no verbal en el rendimiento aritmético. Participaron 126 niños de entre 6 y 11 años. Los instrumentos fueron: Prueba de Rendimiento Escolar, Matrices Progresivas de Raven, Cubes de Corsi y Subprueba Dígitos. Los resultados mostraron correlaciones fuertes y positivas en el rendimiento escolar con inteligencia fluida $r=0,64$ con MT verbal y MT no verbal, ambas con $r=0,51(p<0,001)$. Después de la regresión lineal, se observó que el rendimiento en la MT visuoespacial era fuerte predictor aritmético, efecto no encontrado en lectura. La regresión demostró que MT explica el 38\% de la varianza en la aritmética. Se concluye que la MT tiene una contribución expresiva al rendimiento escolar, siendo las contribuciones visuoespaciales a la aritmética más específicas.
\end{abstract}

Palabras clave: memoria operacional, matemática, niños, rendimiento escolar

\footnotetext{
${ }^{1}$ Universidade Federal da Bahia, Vitória da Conquista-BA, Brazil

${ }^{2}$ Universidade Federal de Minas Gerais, Belo Horizonte-MG, Brazil

Article derived from the PhD dissertation of Fernanda David Vieira, under the supervision of Patrícia Martins de Freitas, defended in 2017, in the Graduate Program in Psychology of the Universidade Federal da Bahia.

Correspondence address: Patricia Martins Freitas. Universidade Federal da Bahia. Rua Hormindo Barros, 58, Quadra 17, Vitória da Conquista-BA, Brazil. CEP 45.029-094. E-mail: patriciafreitasufba@gmail.com
}

Currently, social demands show a strong relationship with technological development, with knowledge in mathematics being a factor associated with employability and better salaries (Gerardi, Goette, \& Meier, 2013). In Brazil, the acquisition of basic knowledge of mathematics has been a major concern before unfavorable statistics, as indicated by the latest results of the PISA (Programme for 
International Student Assessment) exam. According to the results presented in the INEP report (Ministério da Educação, 2019), Brazil had a drop in the average performance, with a worse result for mathematics.

Research on mathematics learning is part of a broader set of studies that compose the line of research on mathematical cognition, also known as numerical cognition (Dorneles, 2019). The development of numerical skills underlies the interaction between knowledge bases about numbers and cognitive mechanisms, such as working memory (WM) (Gonçalves et al., 2017). Exploring which cognitive mechanisms take part in mathematical processing is one of the focuses of this line of research (Fritz, Haase, \& Räsänen, 2019).

WM has been investigated in the context of the development of complex skills, such as learning mathematics. To better understand the relationship between WM and mathematical skills, the following aspects will be presented: the WM model, its relationship with learning and academic performance, and some pieces of evidence on how the model can contribute to explain performance in mathematics.

The theoretical model of WM that has greater coverage is the one developed by Baddeley and Hitch (1974), known as the multicomponent model of WM. This model brings together integrating components of short-term memory with long-term memory, mediated by the executive component and the episodic buffer that manage the processes of information entry, storage, and retrieval. The constituent components of the WM model are organized, differentiating between verbal (phonological loop) and non-verbal (visuospatial sketchpad) information. The phonological loop is activated for decoding, temporary storage, and manipulation of verbal information. Auditory phonological stimuli take part in the construction of a complex system competent for the lexical processing of a given language.

This division has been studied, verifying that the phonological loop of WM has a greater predictive power for learning how to read than the visuospatial sketchpad (Peng et al., 2018). Evidence on the participation of verbal WM for this ability is also robust and shows that children with poor verbal WM have low accuracy in reading (Peng et al., 2018). This component has been described as a predictor of reading performance, which has contributed to the increase in interest in verbal WM training to achieve improvements in this ability in non-reading children.

The visuospatial sketchpad processes non-verbal information, encodes, analyzes, synthesizes, manipulates, and transforms visual patterns, images, spatial location, and shape detection with short-term memory storage (Hitch, Towse, \& Hutton, 2011). For mathematical skills, WM is used to perform arithmetic operations that require the storage of information while the operation continues to be performed (Friso-van den Bos, van der Ven, Kroesbergen, \& van Luit, 2013). On the other hand, the visuospatial sketchpad responsible for image manipulation seems to play a role in the process of learning object recognition and spatial location, and thus would have a greater contribution to numerical acquisition.
School learning depends on access to information; from there, the coding step mediated by the attentional focus retains the teachers' instructions in short-term memory. The contents arrive via verbal stimuli from the oral commands and from images, figures, and objects presented to the students. This initial information must be captured and associated with the ones already existing in the long-term memory. WM is the function responsible for orchestrating most of these cognitive activities, and students who have better scores in this function are more successful in learning school skills (Gathercole \& Alloway, 2004). The ability to store and manipulate information has important implications for school performance. Children who have high performance on WM have higher scores on school performance (Alloway \& Alloway, 2010). In a very general way, one can verify that WM has an important role in the learning processes, with a strong predictive power for school performance. According to the review carried out by Fenesi, Sana, Kim, and Shore (2015), the amplitude of the correlation coefficients between WM and academic performance ranged from $r=0.55$ to $r=0.92$, highlighting the strong relationship between these variables.

Despite the evidence on the influence of WM on academic performance, studies are still needed to assess the contribution of different components of WM to the performance of specific school skills, such as mathematics. According to Cragg, Richardson, Hubber, Keeble, and Gilmore (2017), the number of studies showing the contributions of the visuospatial component to arithmetic and other skills, such as counting and numerical decomposition, is still small. In a study conducted by Holmes, Adams, and Hamilton (2008), the visuospatial component was associated with performance in mathematics, but only for older children. Nevertheless, the measurement of block recall (Corsi blocktapping test) used only the recall of the sequence in the same way that it was presented; therefore, the dimension of the WM evaluated was short-term memory. On the other hand, low performance in visuospatial WM was found in children with learning difficulties in mathematics and with low performance in mathematics. The authors argued that visuospatial WM can contribute to the differentiation between children with typical development and children who have changes in the development of mathematical cognition (Mammarella, Caviola, Giofrè, \& Szücs, 2018).

Moura et al. (2013) observed a moderate correlation between visuospatial WM and numerical writing task, while the correlation was weak with the reading of numbers. The performance of the verbal and visuospatial components are activated to solve arithmetic problems, suggesting that, for mathematical learning, both verbal and non-verbal representations are involved (Imbo \& LeFevre, 2010). The participation of the verbal component was shown in the study by Fürst and Hitch (2000). Similar results were found by Lopes-Silva, Moura, Júlio-Costa, Haase, and Wood (2014), who identified the involvement of the phonological loop in arithmetic operations. In the study by Peng et al. (2018), they found that two components of the WM, phonological loop and the central executive, influence reading. 
The contribution of the verbal and non-verbal components on learning mathematics is still an important research focus. Studies on the effect of each component of WM on learning arithmetic can contribute to a better understanding of the model and validation of the dissociated nature of its components, as well as to properly target cognitive training aimed at improving WM performance, with transfer of cognitive acquisitions to the learning process and school performance (Merkley \& Ansari, 2016; Ofen, Yu, \& Chen, 2016; Swanson, 2016).

The relationship between WM components and school performance in specific skills can achieve greater accuracy, identifying effects of phonological loop and visuospatial sketchpad prediction on arithmetic. This study aimed to investigate the predictive power of verbal and non-verbal working memory (WM) on students' performance in arithmetic.

Considering the evidence already reported in the literature, it is assumed that there is a direct and moderate to strong magnitude relationship between visuospatial WM and performance in arithmetic. For comparative purposes, the following variables were also considered in the sample of this study: fluid intelligence and academic performance in writing and reading.

\section{Methods}

\section{Participants}

The study design was non-experimental, quantitative, and cross-sectional, with a convenience sample. 126 children from 6 to 11 years old took part in the study $(M=8.33$; $S D=1.52$ ), students from the $1^{\text {st }}$ to the $5^{\text {th }}$ grade of elementary school, from two public schools and two private schools in the city of Vitória da Conquista-BA. The composition of this sample was defined after the exclusion of 35 participants, due to a score below the $25^{\text {th }}$ percentile in the intelligence assessment, even after retesting. The retest was applied to verify that the low performance presented could not be an effect of changes in the child's routine, such as tiredness or demotivation. The sex distribution was $57.14 \%(n=72$ children) male. Most children were distributed in the age group of 7 and 10 years old (77.8\%). Regarding the type of school, $43.65 \%$ of the children were from the public network and $56.35 \%$ ( $n=71$ children $)$, from the private network.

\section{Instruments}

Raven's Progressive Color Matrix Test (Angelini, Alves, Custódio, Duarte, \& Duarte, 1999) This instrument aims to assess non-verbal intelligence with evidence of logical reasoning. The intelligence test was used as a criterion for inclusion or exclusion in the sample, in addition to being assessed for its prediction of academic performance and relationship with WM.

Corsi block-tapping test (Orsini, Simonetta, \& Marmorato, 2004) It consists of a task to assess non-verbal WM. It was used to investigate the predictive power of this variable on arithmetic performance. For this study, only the indirect order was used.
Wisc III Digits Subtest/Wechsler Intelligence Scale for Children (Wechsler, 2002) It mainly assesses auditory attention, retention capacity, and verbal WM. Such as the Corsi, it also had the purpose of verifying the predictive power of the WM measurement on arithmetic performance, using, therefore, only the indirect order score. This version of WISC was chosen because it was the approved version of this instrument on the date of the beginning of data collection, which was before the publication and commercialization of WISC IV.

School Achievement Test (SAT) (Stein, 1994) It evaluates, in an objective way, school skills in elementary school. This instrument consists of three subtests: writing, arithmetic, and reading. The SAT indicates, in a comprehensive manner, which areas of school learning have any difficulties. In this study, the main focus was on arithmetic performance. Although there is already a new version, the SAT-II, we inform that this version was published after the beginning of the data collection of this study.

\section{Procedures}

Data collection. The objectives of the research were presented and the Informed Consent Form signatures were collected in meetings in the respective schools. The collection step was carried out only with children who were authorized by their guardians. The tests were applied individually in a reserved room in the schools of the participating children, normally lasting less than 60 minutes. The tests were administered only after the child's consent.

Data analysis. All data processing was performed using functions developed or already available in software R. To meet the objective of the article concerning the exploration of variables, with performance in arithmetic as a dependent variable, the following steps were adopted: Normality test, descriptive statistics for sample description, Correlations, and Multiple Linear Regression.

To verify how school performance is determined based on the explanatory variables, Multiple Linear Regression models were tested. As it is the main focus of this article, regression analyses were performed to test the specific determination of WM on each of the dimensions of academic performance (arithmetic, writing, and reading), excluding the intelligence factor. Although the predominant interest was in the role of WM for performance in mathematics, determination was also measured in writing and reading, as a way of verifying possible impacts of WM on other areas of academic performance. Among the variables of interest, arithmetic performance was adopted as the criterion variable by the arithmetic subtest of the School Performance Test (SAT). The main explanatory variables tested were verbal and non-verbal WM. The fluid intelligence variable was part of the study to identify possible cases of children with performance suggesting intellectual disability. The low score on the intelligence test was defined as an exclusion criterion, to avoid interferences that could make it difficult to measure the role of WM.

For regressions, in addition to the homoscedasticity analysis of the residues, multicollinearity analyses were 
performed, both by verifying the correlation coefficients between the factors that make up the equation and by estimating the variance inflation factor (VIF). VIF values close to 1 are expected, indicating non-inflated variance. Values between 2 and 5 are acceptable, but already indicate a moderate presence of multicollinearity. All variables are of a metric nature and were tested for normality using the Lilliefors Test, in which the null hypothesis $H o$ defends the normality of the variable, with $\alpha=5 \%$ being adopted.

\section{Ethical Considerations}

The study was approved by the Research Ethics Committee of the Universidade Federal da Bahia (CAAE no. 2373713.3.0000.5556, Opinion no. 207,981). The research complied with all ethical standards for research with human beings, having strictly followed Resolutions 466/12 and 510/16 of the Brazilian National Health Council.

\section{Results}

Correlations between variables were tested using Pearson's linear correlation coefficient (Table 1). A strong and positive correlation was found between the total SAT score and the Raven score fluid intelligence $r=0.64$, $p<0.001$, and with the verbal and non-verbal WM measures, both $r=0.51, p<0.001$. When correlating intelligence with the other variables, the result found was a strong and positive correlation between Raven and visuospatial WM (Corsi), $r=0.61$, but a weak and positive one between intelligence and verbal WM (Digits), $r=0.35$. The relationship between verbal $\mathrm{WM}$ and visuospatial WM was $r=0.45$. All dimensions of school performance have moderate and positive correlations, ranging between $r=0.41$ and $r=0.59$ with the measures of WM. For correlations between school performance measures and intelligence, moderate correlations were also found, ranging between $r=0.55$ and $r=0.63$.

Table 1

Correlations between the scores of the variables of the School Performance Test, Raven, Corsi, and Digits

\begin{tabular}{llccccccc}
\hline & 1 & 2 & 3 & 4 & 5 & 6 & 7 \\
\hline 1. Total SAT & 1 & & & & & & \\
2. Arithmetic SAT & $0.70^{* * *}$ & 1 & & & & & & \\
3. Reading SAT & $0.96^{* * *}$ & $0.54^{* * *}$ & 1 & & & & & \\
4. Writing SAT & $0.91^{* * *}$ & $0.66^{* * *}$ & $0.79^{* * *}$ & 1 & & & & \\
6. RAVEN & $0.64^{* * *}$ & $0.62^{* * *}$ & $0.55^{* * *}$ & $0.63^{* * *}$ & $0.38^{* * *}$ & 1 & & \\
7. CORSI & $0.51^{* * *}$ & $0.59^{* * *}$ & $0.41^{* * *}$ & $0.48^{* * *}$ & 0.13 & $0.61^{* * *}$ & 1 & \\
8. DIGITS & $0.51^{* * *}$ & $0.43^{* * *}$ & $0.48^{* * *}$ & $0.50^{* * *}$ & 0.08 & $0.35^{* * *}$ & $0.45^{* * *}$ & 1 \\
\hline
\end{tabular}

Note. SAT $=$ School Achievement Test. $p<0.001 * * *$.

Table 2 and Table 3 show the results found for the regression analyses. In Table 2, Corsi did not present statistical significance, showing no prediction for total school performance (total SAT). The significant variables were then selected using the stepwise method of linear regression, with a coefficient of determination $\left(\mathrm{R}^{2}\right)$ that explains $50 \%$ of the variance of school performance. Both the Corsi block-tapping test and the Digits subtest have a predictive capacity for school performance. The results indicate that the Digits task contributes more to the explanatory model than the Corsi task. The contribution of verbal WM was greater for school performance, considering the total SAT score.

When considering WM variables exclusively, according to the priority focus of this study, writing performance presented statistical significance, with indicators of $F(2.123)=30.34, p<0.001$, and coefficient of determination $\left(\mathrm{R}^{2}\right)$ explaining $32 \%$ of the variance of performance in writing, with the measure of Digits having superior determination power $(\beta=1.37)$ (Table 3$)$.

Table 2

Contribution of Verbal (Digits) and Visuospatial (Corsi block-tapping) for School Performance (total SAT score)

\begin{tabular}{ccccccccc}
\hline & $R$ & $R^{2}$ & $F$ & $D F$ & B & $S D$ & $t$ \\
\hline Corsi & 0.51 & 0.49 & 42.49 & 3.12 & 0.63 & 0.83 & 0.75 \\
Digits & & & & 3.90 & 0.88 & $440^{* * *}$ \\
\hline
\end{tabular}

Note. $\beta=$ line slope coefficient; $S D=$ standard deviation; $R$ multiple; $R^{2}$ adjusted, $F=$ test of variance; $D F=$ degrees of freedom, $p$ : value; $* * * p<0.001$. 
Vieira, F. D., Ribeiro, D. O., Farias, H. B., \& Freitas, P. M. (2021). Working Memory as Predictor of Arithmetic.

Table 3

Multiple Linear Regression Models testing the Corsi and Digits contribution to the Arithmetic, Reading, and Writing SAT score

\begin{tabular}{|c|c|c|c|c|c|c|c|c|c|}
\hline & Models & $R$ & $R^{2}$ & $F$ & $D F$ & $p$ & B & $t$ & $p$ \\
\hline \multirow{2}{*}{ Arithmetic } & Corsi & 0.38 & 0.37 & 37.77 & 2.12 & $<0.001$ & 0.84 & 6.23 & $<0.001$ \\
\hline & Digits & & & & & & 0.43 & 2.57 & 0.01 \\
\hline \multirow{2}{*}{ Reading } & Corsi & 0.27 & 0.26 & 23.57 & 2.12 & $<0.001$ & 1.47 & 0.52 & 0.005 \\
\hline & Digits & & & & & & 2.82 & 4.30 & $<0.001$ \\
\hline \multirow{2}{*}{ Writing } & Corsi & 0.33 & 0.31 & 30.34 & 2.12 & $<0.001$ & 1.02 & 3.91 & $<0.001$ \\
\hline & Digits & & & & & & 1.37 & 4.22 & $<0.001$ \\
\hline
\end{tabular}

Note. Arithmetic - SAT Arithmetic Subtest; Reading - SAT Reading Subtest; Writing - SAT Writing Subtest; $R=$ coefficient of determination; $R^{2}=$ adjusted coefficient of determination; $F=$ test of variance; $\mathrm{DF}=$ degrees of freedom; $p$ : value- $p(<0.05)$; $(\beta)=$ line slope coefficient; $t=\mathrm{t}$-test.

For the determination of arithmetic performance (Table 3), Corsi not only showed statistical significance to predict the equation, but was the factor that best determined arithmetic performance $(\beta=0.84)$. This regression equation was statistically significant, $F(2.123)=37.77$, $p<0.001$, explaining just over $38 \%$ of the performance variance in arithmetic. This model was the one with the best fit $(A I C=389.19)$.

\section{Discussion}

The integration of WM into numerical processing and calculation skills models has been driven by the growing interest in learning mathematics. Mathematical cognition has been the target of interest after the emergence of the triple code model described by Dehaene (1992) to validate and deepen the developed theory. On the other hand, data on the social consequences of poor mathematics performance associated with low wages and low schooling suggest the need to better understand the mathematics learning mechanisms and seek ways to enhance the management of deficits (Dorneles, 2019).

This study aimed to test how much the components of WM, phonological loop and visuospatial sketchpad, predict performance in arithmetic. The domains of mathematics are distinct, and the acquisition of basic operations is essential for the other steps, which include solving more complex problems, such as algebra and equations. Many of the underlying resources that take part in mathematical cognition can also be mediated by visuospatial WM, such as numerical sense, visuospatial processing, and phonological processing (Van de Weijer-Bergsma, Kroesbergen, \& van Luit, 2015). Analyzing how much visuospatial WM can predict performance in arithmetic and whether the predictive power is greater for arithmetic than for reading and writing was the main focus of this study.

The correlations found showed that school performance is best explained by verbal WM. Visuospatial WM was not significant in the model and, therefore, does not take part as a predictor variable. Verbal WM may be contributing more, since two of the subtests, reading and writing, are made up of tasks with verbal items. The participation of verbal WM in school performance has also been identified in other studies (Lopes-Silva et al., 2014; Peng et al., 2018).

Another finding of this study was the strong positive correlation between the fluid intelligence measure (Raven) and the WM measures (Corsi and Digits). The results indicate an association of greater magnitude with Corsi and a moderate one with Digits. According to Singh, Gignac, Brydges, and Ecker (2018), although are different constructs, there is empirical evidence for a link between the two variables. As expected, the data also show a positive and strong correlation between the two measures of WM, since both Corsi and Digits propose to verify dimensions of the same variable.

Regarding the research hypothesis, a direct and moderate magnitude relationship between WM and arithmetic performance was obtained $(r=0.43$ with Digits and $r=0.59$ with Corsi), confirming the importance of the visuospatial component for the skills of performing mathematical operations. The visuospatial dimension is highlighted in a study on mathematical cognition. Although some studies show how verbal WM also contributes to the resolution of mathematical operations, the importance of pictorial elements in numerical representation, the position of numbers, and their distribution in mental images for performing calculations place visuospatial $\mathrm{WM}$ as a component that should be more valued in the assessment of math learning difficulties (Morosanova, Fomina, Kovas, \& Bogdanova, 2016; Rittle-Johnson, Zippert, \& Boice, 2018).

When analyzing the results of the regressions for the sample of this study, there is evidence of the relevance of WM for academic performance, as well as the specificities of its components for specific school skills. Visuospatial WM showed a predictive power for performance in arithmetic and writing, with no significance for reading and total performance. The actions of writing and solving numerical problems seem to require the manipulation of visual information with a specific demand for retrieval and retention of content in visuospatial 
WM, demanding a lot from this function (Kellogg, Turner, Whiteford, \& Mertens, 2016; Swanson, 2016).

The evidence found shows that the influence of WM (verbal and visuospatial) was estimated at $38 \%$ of the variance of arithmetic performance. The Corsi block-tapping was the variable that best determined the performance in arithmetic, showing an important contribution of this function to the activities of numerical calculations. Swanson (2016) found, in an experimental research with group comparison carried out with 162 American elementary school children who had difficulties in mathematics, that the children varied regarding the capacity of WM, not being compared as to the components of WM. After exposure to certain pedagogical strategies, the author found that teaching results were moderated by memory, so that children with high WM outperformed those with low performance in this component in all post-test assessments. The results suggest that WM functions as a bottleneck for performance in the mathematical skills of solving arithmetic problems, calculating, and size of the numerical operation. The study, however, does not specify how each component of WM contributes to mathematical skills (Swanson, 2016).

The results showed an important role of WM for solving mathematical operations. Difficulties in arithmetic calculations can interfere with other areas of an individual's life, such as the ability to handle the use of money, handle medication administration, or even follow a cooking recipe, examples of daily activities involving numbers and arithmetic operations. The role of WM is evident in solving mathematical problems that activate a variety of mental activities, which requires the parts to be pre-stored to ensure the solution of the entire problem (Swanson, 2016).

The evidence obtained in this study with the correlations and regressions reaffirms the importance of the visuospatial component of WM for the best performance in arithmetic, which is one of the basic domains for skills in mathematics. Poor calculating skills impact the reach of more complex skills, significantly limiting a good mathematics performance (Dorneles, 2019). These findings are consistent with the description of Geary (2010) on the centrality of WM and the visuospatial component for solving numerical problems, as a function of limited capacity, which has the responsibility of preserve and concurrently process the content (a mathematical problem, for example) that is currently running. Research indicates that the advantages for children with good WM capacity occur because the strategies depend on representations and cognitive processes that use the representation by images and position of the numbers with strategies that involve the movement of the numbers in the mental image as a calculation strategy (Swanson, 2016).

Evidence on the strong contribution of WM to school performance is also reported by two research axes, one aimed at identifying WM deficits in learning disorders, especially dyslexia and dyscalculia (Haase et al., 2014; Lopes Silva, Moura, Wood, \& Haase, 2015) and the other constituting a set of studies with positive results after cognitive training aimed at better WM performance (Peng et al., 2018; Sala \& Gobet, 2017; Schwaighofer, Fischer, \& Bühner, 2015). Some studies on
WM training show better performance in school skills, results called distal transfer when the improvement is positive in skills that were not directly trained (Gathercole \& Alloway, 2004; Peijnenborgh, Hurks, Aldenkamp, Vles, \& Hendriksen, 2016; Sánchez-Pérez et al., 2018). Considering the WM model, we can highlight that numerical skills are subordinate to the components of the visuospatial sketchpad and executive buffer, as shown in the studies by Layes, Lalonde, Bouakkaz, and Rebai (2018) and Sánchez-Pérez et al. (2018). Current evidence indicates that visuospatial WM is an especially deficient component in children with difficulties in this discipline (Menon, 2016).

After the results obtained in this study, it was possible to reinforce the evidence of the relationship between WM and general school performance and the specificities of the predictive power for arithmetic, one of the skills of mathematical processing. The findings may contribute to the development of a cognitive stimulation program that considers WM training and especially visuospatial components in the early years of the acquisition of arithmetic operations. We believe that interventions can move in the direction of also seeking to stimulate the visuospatial sketchpad of WM, which will result in direct gains in the student's ability with numbers. The following limitations were identified: reduced and convenience sample; assessment of other dimensions of mathematical cognition, such as magnitude estimation and numerical transcoding; differentiation between the type of arithmetic operations; assessing other cognitive measures, such as processing speed, planning and problem solving; and the need for computerized investigations, controlling variables such as reaction time. For future studies, it is important that the limitations of this research can be overcome to expand the frameworks that underlie research on WM and learning mathematics. Despite the limitations, this study advances in identifying a strong predictive power of WM for performance in arithmetic with emphasis on visuospatial WM.

\section{References}

Alloway, T. P., \& Alloway, R. G. (2010). Investigating the predictive roles of working memory and IQ in academic attainment. Journal of Experimental Child Psychology, 106(1), 20-29. doi:10.1016/j.jecp.2009.11.003

Angelini, A. L., Alves, I. C. B., Custódio, E. M., Duarte, W. F., \& Duarte, J. L. M. (1999). Matrizes progressivas coloridas de RAVEN: Escala especial: Manual [Raven's coloured progressive matrices: Special scale: Handbook]. São Paulo, SP: CETEPP.

Baddeley, A. D., \& Hitch, G. (1974). Working memory. In G. H. Bower (Ed.), The psychology of learning and motivation: Advances in research and theory (Vol. 8, pp. 47-89). New York, NY: Academic Press.

Cragg, L., Richardson, S., Hubber, P. J., Keeble, S., \& Gilmore, C. (2017). When is working memory important for arithmetic? The impact of strategy and age. PloS One, 12(12), e0188693. doi:10.1371/journal.pone.0188693 
Dehaene, S. (1992). Varieties of numerical abilities. Cognition, 44(1-2), 1-42. doi:10.1016/0010-0277(92)90049-n

Dorneles, B. V. (2019). Mathematical learning and its difficulties in Latin-American countries. In A. Fritz, V. G. Haase, \& P. Räsänen (Eds.), International handbook of mathematical learning difficulties: From the laboratory to the classroom (pp. 201-212). Cham, Switzerland: Springer.

Fenesi, B., Sana, F., Kim, J. A., \& Shore, D. I. (2015). Reconceptualizing working memory in educational research. Educational Psychology Review, 27(2), 333-351. doi:10.1007/s10648-014-9286-y

Friso-van den Bos, I., van der Ven, S. H. G., Kroesbergen, E. H., \& van Luit, J. E. H. (2013). Working memory and mathematics in primary school children: A meta-analysis. Educational Research Review, 10, 29-44. doi:10.1016/ j.edurev.2013.05.003

Fritz, A., Haase, V. G., \& Räsänen, P. (2019). International handbook of mathematical learning difficulties: From the laboratory to the classroom. Cham, Switzerland: Springer.

Fürst, A. J., \& Hitch, G. J. (2000). Separate roles for executive and phonological components of working memory in mental arithmetic. Memory \& Cognition, 28(5), 774-782. doi:10.3758/BF03198412

Gathercole, S. E., \& Alloway, T. P. (2004). Working memory and the classroom learning. Dyslexia Review, 15(3), 4-9. Retrieved from https://www.researchgate.net/ publication/254392644_Working_memory_and_ classroom_learning

Geary, D. C. (2010). Mathematical disabilities: Reflections on cognitive, neuropsychological, and genetic components. Learning and Individual Differences, 20(2), 130-133. doi:10.1016/j.lindif.2009.10.008

Gerardi, K., Goette, L., \& Meier, S. (2013). Numerical ability predicts mortgage default. Proceedings of the National Academy of Sciences of the United States of America, 110(28), 11267-11271. doi:10.1073/pnas.1220568110

Gonçalves, H. A., Viapiana, V. F., Sartori, M. S., Giacomoni, C. H., Stein, L. M., \& Fonseca, R.P. (2017). Funções executivas predizem o processamento de habilidades básicas de leitura, escrita e matemática? [Executive functions predict the processing of basic reading, writing, and mathematics skills?]. Neuropsicologia Latinoamericana, 9(3), 42-54. Retrieved from https://www.neuropsicolatina.org/index. php/Neuropsicologia_Latinoamericana/article/view/393

Haase, V. G., Júlio-Costa, A., Lopes-Silva, J. B., StarlingAlves, I., Antunes, A. M., Pinheiro-Chagas, P., \& Wood, G. (2014). Contributions from specific and general factors to unique deficits: Two cases of mathematics learning difficulties. Frontiers in Psychology, 5, 102. doi:10.3389/ fpsyg.2014.00102

Hitch, G. J., Towse, J. N., \& Hutton, U. (2011). What limits children's working memory span? Theoretical accounts and applications for scholastic development. Journal of Experimental Psychology: General, 130(2), 184-198. doi:10.1037//0096-3445.130.2.184
Holmes, J., Adams, J. W., \& Hamilton, C. J. (2008). The relationship between visuospatial sketchpad capacity and children's mathematical skills. European Journal of Cognitive Psychology, 20(2), 272-289. doi:10.1080/09541440701612702

Imbo, I., \& LeFevre, J. (2010). The role of phonological and visual working memory in complex arithmetic for Chinese- and Canadian-educated adults. Memory \& Cognition, 38(2), 176-185. doi:10.3758/MC.38.2.176

Kellogg, R. T., Turner, C. E., Whiteford, A. P., \& Mertens, A. (2016). The role of working memory in planning and generating written sentences. Journal of Writing Research, 7(3), 397-416. doi:10.17239/jowr-2016.07.03.04

Layes, S., Lalonde, R., Bouakkaz, Y., \& Rebai, M. (2018). Effectiveness of working memory training among children with dyscalculia: Evidence for transfer effects on mathematical achievement-a pilot study. Cognitive Processing, 19(3), 375-385. doi:10.1007/s10339-017-0853-2

Lopes-Silva, J. B., Moura, R., Júlio-Costa, A., Haase, V. G., \& Wood, G. (2014). Phonemic awareness as a pathway to number transcoding. Frontiers in Psychology, 5, 13. doi:10.3389/fpsyg.2014.00013

Lopes Silva, J. B., Moura, R. J., Wood, G., \& Haase, V. G. (2015). Processamento fonológico e desempenho em aritmética: Uma revisão da relevância para as dificuldades de aprendizagem [Phonological processing and mathematic performance: A review of the relevance to learning disabilities]. Temas em Psicologia, 23(1), 157-173. Retrieved from http:// pepsic.bvsalud.org/scielo.php?script=sci_arttext\&pid= S1413-389X2015000100012\&lng=pt\&tlng=pt

Mammarella, I. C., Caviola, S., Giofrè, D., \& Szücs, D. (2018). The underlying structure of visuospatial working memory in children with mathematical learning disability. The British Journal of Developmental Psychology, 36(2), 220-235. doi:10.1111/bjdp.12202

Menon, V. (2016). Working memory in children's math learning and its disruption in dyscalculia. Current Opinion in Behavioral Sciences, 10, 125-132. doi:10.1016/ j.cobeha.2016.05.014

Ministério da Educação. Instituto Nacional de Estudos e Pesquisas Educacionais Anísio Teixeira. (2019). Relatório Brasil no PISA 2018: Versão preliminar [Brazil Report at PISA 2018: Preliminary version]. Brasília, DF: INEP/ MEC. Retrieved from https://download.inep.gov.br/ acoes_internacionais/pisa/documentos/2019/relatorio_ PISA_2018_preliminar.pdf

Merkley, R., \& Ansari, D. (2016). Why numerical symbols count in the development of mathematical skills: Evidence from brain and behavior. Current Opinion in Behavioral Sciences, 10, 14-20. doi:10.1016/j.cobeha.2016.04.006

Morosanova, V. I., Fomina, T. G., Kovas, Y., \& Bogdanova, O. Y. (2016). Cognitive and regulatory characteristics and mathematical performance in high school students. Personality and Individual Differences, 90, 177-186. doi:10.1016/j.paid.2015.10.034 
Moura, R., Wood, G., Pinheiro-Chagas, P., Lonnemann, J., Krinzinger, H., Willmes, K., \& Haase, V. G. (2013). Transcoding abilities in typical and atypical mathematics achievers: The role of working memory and procedural and lexical competencies. Journal of Experimental Child Psychology, 116(3), 707-727. doi:10.1016/ j.jecp.2013.07.008

Ofen, N., Yu, Q., \& Chen, Z. (2016). Memory and the developing brain: Are insights from cognitive neuroscience applicable to education? Current Opinion in Behavioral Sciences, 10, 81-88. doi:10.1016/ j.cobeha.2016.05.010

Orsini, A., Simonetta, S., \& Marmorato, M. S. (2004). Corsi's block-tapping test: Some characteristics of the spatial path which influence memory. Perceptual and Motor Skills, 98(2), 382-388. doi:10.2466/pms.98.2.382-388

Peijnenborgh, J. C., Hurks, P. M., Aldenkamp, A. P., Vles, J. S., \& Hendriksen, J. G. (2016). Efficacy of working memory training in children and adolescents with learning disabilities: A review study and metaanalysis. Neuropsychological Rehabilitation, 26(5-6), 645-672. doi:10.1080/09602011.2015.1026356

Peng, P., Barnes, M., Wang, C., Wang, W., Li, S., Swanson, H. L., ...Tao, S. (2018). A meta-analysis on the relation between reading and working memory. Psychological Bulletin, 144(1), 48-76. doi:10.1037/bul0000124

Rittle-Johnson, B., Zippert, E. L., \& Boice, K. L. (2018). The roles of patterning and spatial skills in early mathematics development. Early Childhood Research Quarterly, 46, 166-178. doi:10.1016/j.ecresq.2018.03.006

Sala, G., \& Gobet, F. (2017). Working memory training in typically developing children: A meta-analysis of the available evidence. Developmental Psychology, 53(4), 671-685. doi:10.1037/dev0000265

Sánchez-Pérez, N., Castillo, A., López-López, J. A., Pina, V., Puga, J. L., Campoy, G., ... Fuentes, L. J. (2018). Computer-based training in math and working memory improves cognitive skills and academic achievement in primary school children: Behavioral results. Frontiers in Psychology, 8, 2327. doi:10.3389/fpsyg.2017.02327

Schwaighofer, M., Fischer, F., \& Bühner, M. (2015). Does working memory training transfer? A meta-analysis including training conditions as moderators. Educational Psychologist, 50(2), 138-166. doi:10.1080/00461520. 2015.1036274

Singh, K. A., Gignac, G. E., Brydges, C. R., \& Ecker, U. K. H. (2018). Working memory capacity mediates the relationship between removal and fluid intelligence. Journal of Memory and Language, 101, 18-36. doi:10.1016/j.jml.2018.03.002

Stein, L. M. (1994). TDE: Teste de Desempenho Escolar: Manual para aplicação e interpretação [TDE: School Performance Test: Manual for application and interpretation]. São Paulo, SP: Casa do Psicólogo.
Swanson, H. L. (2016). Word problem solving, working memory and serious math difficulties: Do cognitive strategies really make a difference? Journal of Applied Research in Memory and Cognition, 5(4), 368-383. doi:10.1016/j.jarmac.2016.04.012

Van de Weijer-Bergsma, E., Kroesbergen, E. H., \& van Luit, J. E. H. (2015). Verbal and visual-spatial working memory and mathematical ability in different domains throughout primary school. Memory \& Cognition, 43(3), 367-378. doi:10.3758/s13421-014-0480-4

Wechsler, D. (2002). WISC-III: Escala de Inteligência Wechsler para crianças: Manual [WISC-III: Wechsler Intelligence Scale for Children: Handbook] (V. L. M. Figueiredo, Trans., 3rd ed.). São Paulo, SP: Casa do Psicólogo.

Fernanda David Vieira is a Psychologist and Researcher of the Universidade Federal da Bahia, Vitória da Conquista-BA, Brazil.

Denise Oliveira Ribeiro is a Master's Degree Student by the Graduate Program in Psychology: Cognition and Behavior of the Federal Universidade Federal de Minas Gerais, Belo Horizonte-MG, Brazil.

Heitor Blesa Farias is a Master's Degree Student of the Graduate Program in Psychology: Cognition and Behavior of the Universidade Federal de Minas, Belo Horizonte-MG, Brazil.

Patricia Martins Freitas is a Professor of the Universidade Federal da Bahia, Vitória da Conquista-BA, Brazil.

Authors' Contribution:

All authors made substantial contributions to the conception and design of this study, to data analysis and interpretation, and to the manuscript revision and approval of the final version. All the authors assume public responsibility for content of the manuscript.

Associate Editor:

Vanessa Barbosa Romera Leme

Received: Jun. 05, 2020

1st Revision: Oct. 27, 2020

2nd Revision: Jan. 15, 2021

Approved: Feb. 11, 2021

How to cite this article:

Vieira, F. D., Ribeiro, D. O., Farias, H. B., \& Freitas, P. M. (2021). The working memory as predictor of performance in arithmetic of Brazilian students. Paidéia (Ribeirão Preto), 31, e3119.doi:https://doi.org/10.1590/1982-4327e3119 